\title{
Çinko uygulamasının çeltik (Oryza sativa L.) çeşitlerinde bazı kalite özellikleri üzerine etkisi*
}

\author{
Nuri YILMAZ ${ }^{1}$, M. Cihan SONKAYA ${ }^{2}$ \\ ${ }^{1}$ Ordu Üniversitesi Ziraat Fakültesi Tarla Bitkileri Bölümü, ORDU \\ ${ }^{2}$ Ordu Üniversitesi Fen Bilimleri Enstitüsü Tarla Bitkileri Anabilim Dalı, ORDU \\ *Yüksek Lisans çalışmasından alınmış olup, ODÜ BAP birimi tarafından desteklenmiștir (Proje No:TF-1456). \\ Alınış tarihi: 07 Eylül 2017, Kabul tarihi: 04 Mayıs 2018 \\ Sorumlu yazar: Nuri YILMAZ, e-posta:y_nuri@hotmail.com
}

\section{Öz}

$\mathrm{Bu}$ araştırma; çeltik (Oryza sativa L.) çeşitlerinde çinko uygulamasının bazı kalite özellikleri üzerine etkilerinin belirlenmesi amacıyla yürütülmüștür. Araştırmada sera koşullarında 4 farklı çeltik çeşidi kullanılarak (Efe, Hamzadere, Osmancık-97 ve Paşalı) 5 farklı çinko dozu $(0,5,10,15,20 \mathrm{mg} / \mathrm{kg})$ uygulanmiştır. Tesadüf parselleri deneme desenine göre, faktöriyel düzenlemede üç tekerrürlü olarak saksılarda yürütülmüştür. Deneme sonucunda; Çeşitlere uygulanan çinko dozlarının kaliteye dönük etkisi, kırıksız randıman hariç, bin tane ağırlığı, pirinç tane uzunluğu, pirinç tane genişliği ve protein oranına etkisi istatistiki olarak önemli bulunmuştur. Genel olarak tüm çeşitlerde çinko uygulamalarının belirli bir doza kadar (10 ve $15 \mathrm{mg}$ ) olumlu etki, daha sonra olumsuz yönde etkilediği görülmüştür. Bu sonuçlara göre, kullanılan 4 çeltik çeşidinde de $\mathrm{Zn}$ kullanılmasının gerektiği, fakat bunun toprak tahlili sonucuna göre uygulanması gerektiği sonucuna varılmiştır.

Anahtar kelimeler: Çeltik, Oryza sativa, çinko, kalite

Determine the effect of zinc on some quality properties of some rice (Oryza sativa $L_{\text {.) }}$ varieties

\author{
Abstract \\ This research was carried out to determinate the \\ effect of Zinc on some quality properties of some rice \\ genotypes (Oryza sativa L.). In this study were used \\ four different rice genotypes (Efe, Hamzadere, \\ Osmancık-97 and Pasalı) and 5 different doses of
}

zinc $\left(0,5,10,15,20 \mathrm{mg} \mathrm{ZnSO}_{4} / \mathrm{kg}\right)$ under greenhouse conditions. Pot experiments were conducted according to the completely randomized design with 3 replicates. According to the result of research, zinc applications were found statistically significant in 1000 seed/grain weight, rice seed/grain length, rice seed/grain width, protein ratio however those applications weren't found statistically importance difference on rice performance without cracked seed. On overall evaluation of result, zinc applications had a positive impact on the all genotypes reach up to a spesific dose (10 and $15 \mathrm{mg}$ ) after that it was had a negative impact on. As a result of datas, zinc must be used of those 4 rice genotypes. But zinc applications should be apply after the soil analysis completed.

Key words: Rice, Oryza sativa, zinc, quality

\section{Giriş}

Tahıllar canlıların beslenmesinde önemli bir yere sahip olup, dünyada ve ülkemizde geniş ekim alanlarının büyük bir kısmında yetiştirilmektedir. Tahıllar içerisinde çeltik, dünya'da ekim alanı yönünden buğdaydan, üretimde ise mısırdan sonra ikinci sırada gelmekte olup dünya nüfusunun yarısından fazlasının temel besinidir. 1990 ve 2025 yılları arasında, dünya çeltik üretiminin, artan dünya nüfusunu besleyebilmesi için yılda \% 1.7 oranında artması gerekmektedir. Çeltik dünyada gıda güvenliği ve fakirlikle mücadele için uzun yıllardır yetiştirilmesi nedeniyle kültürel mirasın korunması ve sürdürülebilir gelişmenin sağlanması açısından çok önem taşımaktadır (Sürek, 2005). Bitki 
yetiștiriciliğinde tek amaç bol ve kaliteli ürünler elde etmektir. Bunun için bitkinin yetişeceği ortamın iyi hazırlanması gerekir. Özellikle de düzensiz drenaj koşullarında yapılan çeltik tarımı, bazı çevresel sorunları da beraberinde getirmektedir. Bu sorunlar; toprak veriminin azalması, tuzluluk, belirli alanlarda su birikintilerinin oluşması, kimyasal gübreler, kimyasal ilaçlar nedeniyle çeşitli kaynaklarda oluşan su kirliliği ve dolaylı olarak insan sağlığına zararlı koşulların oluşması şeklinde sorunların olduğu belirtilmektedir (Dok ve ark., 2013, Sezer ve Mut, 2004, Sezer ve ark., 2012, Sezer ve ark., 2015, Sezer ve ark., 2017). Bitki yetiştiriciliği için toprakla ilgili olarak tarımsal çalışma ve üretimde gerekli olan nokta, toprağın verimlilik özelliğinin korunması ve artırılması ile ilgili önlemlerin alınması yanında, toprağa üretkenlik kazandırmayı da ekleyebiliriz. Bu önlemlerin başında ise, sürekli bitki yetiştirilmesiyle besin element dengesi bozulan topraklara organik veya inorganik besin maddelerinin eklenmesi gelmektedir. Bitkisel üretimde sadece makro besin elementleri değil onlar kadar önemi ve işlevleri olan mikro besin elementlerinin de toprakta yeteri kadar bulunması veya bitkinin ihtiyaç duyduğu kadar uygulanması gerekmektedir. Fakat ülkemizde daha çok azotlu, fosforlu ve potasyumlu gübrelemeye ağırlık verilmektedir. Mikro elementler ve bunun içerisinde özelliklede çinkolu (Zn) gübreleme pek dikkate alınmamaktadır. Çinkonun bitkilerdeki işlevi azot, fosfor, potasyum gibi makro besin elementleri kadar önemlidir. Bu nedenle kaliteli ve bol ürün alınabilmesi için bitkilerin geliştikleri ortamda çinkoyu bulmaları, yeterli miktarda almaları ve gerektiği şekilde kullanmaları için çinko büyük önem taşır. Ülkemizde tarım arazilerinin yaklaşık \% 50'sinin yarayışlı çinko yönünden fakir durumda olması, bitkilerde çinko noksanlığına neden olmaktadır. Buna bağlı olarak da tahıla dayalı beslenmenin yoğun olduğu bölgelerde bazı sağlık sorunları ortaya çıkmaktadır. Ülkemiz gibi beslenmesi genelde bitkisel ürünlere ve özellikle tahıla dayalı ülkelerde çinko beslenmesi daha da önem taşımaktadır (Arcasoy, 1997). Çeltik çinko noksanlığına hassas bir bitki olduğundan dolayı çeltik tür ve çeşitlerinde çinko noksanlığına ve uygulamalarına karşı tepkiler farklı olmaktadır. Ancak bitkilerde çinko eksikliğine karşı dayanıklılık durumu tam olarak bilinmemektedir. Bu nedenle son yıllarda topraktaki çinkodan daha iyi yararlanabilen çeșitlerin belirlenmesi için önemli çalıșmalar yapılmaktadır. Çinko eksikliğinden etkilenen bitkilerde kardeșlenme gecikir, kardeş sayısında azalma görülür, olgunlașma gecikir, verim ve kalite azalır (Sürek, 2005).

Bu bağlamda çalışma ile farklı dozlardaki çinkonun bazı çeltik (Oryza sativa L.) çeşitlerinde kaliteye olan etkisinin belirlenmesi amaçlanmıştır.

\section{Materyal ve Yöntem}

\section{Materyal}

Araştırma 2014 yılında, Ordu Üniversitesi Ziraat Fakültesi Tarla Bitkileri Bölümü araştırma serasında ve laboratuvarında yürütülmüştür. Denemede 4 çeltik çeşidi Osmancık-97, Efe, Hamzadere ve Paşalı kullanılmıştır. Çeşitlerin tamamı Trakya Tarımsal Araștırma Enstitüsünden (Edirne) temin edilmiștir. Denemede kullanılan toprak; Ordu il sınırları içerisinde tarım yapılan alanlardan seçilerek alınmıştır. Denemede kullanılan toprak örneği temiz bir zemin üzerinde $4 \mathrm{~mm}$ 'lik elekten geçirildikten sonra kuru hale gelinceye kadar bekletilmiştir. Denemede kullanılan toprak; kumlu tınlı tekstüre sahip olup, hafif alkali, tuzsuz, orta seviyede kireçli, organik maddesi çok az, azot ve fosfor ve potasyum yetersiz olarak belirlenmiștir. Deneme toprağının mikro element içerikleri ise demir ve bakır konsantrasyonu yeterli, mangan konsantrasyonu az, çinko konsantrasyonu fazla olarak belirlenmiștir.

\section{Yöntem}

Deneme 12 Temmuz 2014'te kurulmuş olup, 5 Kasım 2014 tarihinde hasat edilmiştir. Deneme tesadüf parselleri deneme deseninde, faktöriyel düzenlemelere göre 4 farklı çeltik çeşidi (Osmancık97, Efe, Hamzadere ve Paşalı), 5 farklı çinko dozu $(0,5,10,15,20 \mathrm{mg} / \mathrm{kg} \mathrm{Zn})$ ve 3 tekrarlamalı olarak kurulmuştur. Her saksıya $10 \mathrm{~kg}$ olacak șekilde elenmiş kuru toprak doldurulmuştur. Saksılara doldurulan topraklar ekimden önce elle malçlama yapılarak ekime hazırlanmıştır. Ekim öncesi tohumlar ise 24 saat tamamen su içerisinde bekletildikten sonra nemli bir bez üzerinde 24 saat daha bekletilerek ön çimlendirme işlemi yapılmıştır. Tohumlar ön çimlendirme işlemi yapıldıktan sonra her saksıya 20 tohum gelecek şekilde ekim işlemi yapılmıştır. Ekim sonrası temel gübre olarak 10-1010 gübresinden $500 \mathrm{gr}$ miktarında gübre 18.5 litrelik suda çözülerek her saksıya $100 \mathrm{ml}$ gelecek şekilde uygulanmıştır. Bitkilerin tamamı çıkış yaptıktan sonra denemede uygulanacak olan çinko, çinko sülfat gübresi $\left(\mathrm{ZnSO}_{4}\right)$ olarak uygulanmıștır. Çinko gübresi her doz için (Zno:0, Zn1:5, Zn2:10, Zn3:15, Zn4:20 $\mathrm{mg} / \mathrm{kg} \quad \mathrm{Zn}$ olarak çinko sülfat kaynağından sağlanmıştır.) ayrı ayrı hesaplanmıştır. 1.5 litre su 
içerisinde çözülerek her saksıya 100 ml olacak şekilde uygulama işlemi yapılmıştır. Ekim tarihi ile birlikte 20 Ekim tarihine kadar sulama işlemi devam etmiştir ve yabancl ot mücadelesi el ile yolunarak yapılmıştır. Hasat 5 Kasım 2014 tarihinde bitkilerin tamamı olgunlaşma dönemine geldiği zaman yapılmıştır. Denemede bin tane ağırlı̆̆l (g), pirinç tane uzunluğu $(\mathrm{mm})$, pirinç tane genişliği (mm) kırıksız pirinç randımanı (\%) ve protein oranı gibi özellikleri incelenmiştir. İstatistiksel değerlendirmede SAS-JMP paket programı ve çoklu karşılaştırmalar için LSD testi kullanılmıştır.

\section{Bulgular ve Tartışma \\ Bin tane ağırlığı}

Denemede kullanılan çeltik çeşitleri ve çinko uygulamalarının bin tane ağırlığına etkisine ait ortalama değerler Çizelge 1'de verilmiştir.
Çizelge 1'in incelenmesinden anlaşılacağı üzere çeşit, çinko uygulaması ve çeşit $x$ çinko uygulama interaksiyonu' nun bin tane ağırlığı üzerine etkisi istatistiksel olarak önemli görülmüştür.

Denemede kullanılan çinko uygulamalarının bin tane ağılığına etkisi çeşitlere göre değişiklik göstermiştir. Çizelge 1'de çeşit x çinko uygulamaları interaksiyonu incelendiğinde bin tane ağırlığı en yüksek Hamzadere çeşidinin Zn2 uygulamasından (41.4 g), en düşük bin tane ağırlığı ise Paşalı çeşidinin Zn3 uygulamasından (36.54 g) elde edildiği görülmektedir. Hamzadere ve Paşalı çeşitlerinde çinko uygulama dozu artışında bin tane ağırlığında azalmalar görülürken, Osmancık-97 çeşidin de Zn1 uygulamasından sonra çinko artışı ile bin tane ağırlığında artış görülmüştür. Çinko uygulamasının Efe çeşidinin bin dane ağılığında etkisinde ise belirgin bir değişikliğin olmadığı görülmüștür.

Çizelge 1. Çinko uygulamasının çeltik çeşitlerinde bin tane ağırlığı (g) üzerine etkileri ve gruplandırması

\begin{tabular}{|c|c|c|c|c|c|c|}
\hline \multirow{2}{*}{ Çeşitler } & \multicolumn{5}{|c|}{ Uygulama } & \multirow[b]{2}{*}{ Ort. } \\
\hline & 0 & $\mathrm{Zn} 1$ & $\mathrm{Zn} 2$ & $\mathrm{Zn} 3$ & $\mathrm{Zn} 4$ & \\
\hline Efe & $38.20 \mathrm{c}$ & $39.31 \mathrm{~b}$ & $38.34 \mathrm{c}$ & $39.58 \mathrm{~b}$ & $38.23 \mathrm{c}$ & $38.73 \mathrm{~B}$ \\
\hline Hamzadere & $41.35 \mathrm{a}$ & $40.80 \mathrm{a}$ & $41.40 \mathrm{a}$ & $38.30 \mathrm{c}$ & $39.47 \mathrm{~b}$ & $40.26 \mathrm{~A}$ \\
\hline Osmancık- 97 & $38.26 \mathrm{c}$ & $35.92 \mathrm{~g}$ & $37.89 \mathrm{~cd}$ & $37.99 \mathrm{~cd}$ & $39.88 \mathrm{~b}$ & $37.99 \mathrm{C}$ \\
\hline Paşalı & $38.16 \mathrm{c}$ & $37.22 \mathrm{de}$ & $37,81 \mathrm{~cd}$ & $36.54 \mathrm{fg}$ & 36.84 ef & $37.33 \mathrm{D}$ \\
\hline Ort. & $39.0 \mathrm{~A}$ & $38.33 \mathrm{CD}$ & $38.86 \mathrm{AB}$ & $38.1 \mathrm{D}$ & $38.6 \mathrm{BC}$ & \\
\hline
\end{tabular}

LSD çeșit $=0.326$ LSD uygulama $=0.364$ LSD çeșit $x$ uyg. int $=0.729$

Özcan (2004), çeltik bitkisinde çinko uygulaması ile yapmıș olduğu çalıșmada bin tane ağırlığını ortalama $26.85 \mathrm{~g}$ bulurken çinko dozu uyguladıkça bin tane ağırlığının \% 2.7 oranında düştüğünü belirtmiştir. Diğer çalışmalarda Zeng ve ark. (2001), çalışmalarında bin tane ağırlığını 20-52 g, Abid ve ark. (2002), bin tane ağırlığını ortalama $23.93 \mathrm{~g}$, Bakhtavarı ve Tahmasebi, (2011), bin tane ağırlığını 36.52 ile 36.71 g, Ünan (2011), bin tane ağırlığını 31.4-37.7 g, Sezer ve Köycü (1999), bin dane ağırlığını 30.4-41.2 g arasında değiștiği belirtilmiştir. Yapmiş olduğumuz çalışma sonucunda bin tane ağırlığı diğer çalışmalar içerisinde Zeng ve ark. (2001) ve Sezer ve Köycü (1999)'nün yaptığı çalışmalar ile benzerlik gösterirken diğer çalışmalara göre bin tane ağırlığı fazla bulunmuştur.

\section{Pirinç tane uzunluğu}

Denemede kullanılan çeltik çeşitleri ve çinko uygulamalarının pirinç tane uzunluğuna etkisine ilişkin ortalama değerler Çizelge 2'de verilmiştir. Çalışmada çeşit, çinko uygulaması ve çeşit x çinko uygulama interaksiyonunun pirinç tane uzunluğu üzerine etkisi istatistiksel olarak önemli görülmüştür. Kullanılan çinko uygulamalarının pirinç tane uzunluğuna etkisi çeşitlere göre değişiklik göstermiştir. Pirinç tane uzunluğu en kısa 5.77 mm ile Paşalı çeşidinin Zn3 uygulamasından, en uzun pirinç uzunluğu ise $6.19 \mathrm{~mm}$ ile Hamzadere çeşidinin Zn3 uygulamasından elde edilmiştir. Hamzadere çeşidinde Zn3 uygulamasına kadar tane uzunluğunda artış olmuş sonra azalmıştır. Osmancık-97 çeşidinde çinko dozu arttıkça pirinç tane uzunluğunda artış görülmüştür. Diğer çeşitlerde ise kontrol uygulamasına göre artış olurken doz arttıkça farklı değişim görülmüştür. Genel olarak kontrol uygulamasına göre çinko dozunun artışı pirinç tane uzunluğunda artışa neden olmuştur. Toksal (1991), yapmış olduğu çalışmasında pirinç tane uzunluğunu 7.68-5.18 $\mathrm{mm}$ arasında, Can (2011), çalışmasında pirinç tane uzunluğunu ortalama $7.0 \mathrm{~mm}$ bulurken, Hakoomat ve ark. (2014), ise ortalama pirinç tane uzunluğunu 4.95 mm olarak bulmuştur. Zeng ve ark. (2001), çalışma sonucunda çeltik tane uzunluğunu 5 ila $13 \mathrm{~mm}$ arasında bulmuştur. Çalışma sonucunda bulduğumuz değerler Toksal (1991), Can (2011) ve Hakoomat ve ark. (2014), sonuçları ile benzerlik göstermektedir. 
Çizelge 2. Çinko uygulamasının çeltik çeşitleri pirinç tane uzunluğu (mm) üzerine etkileri ve gruplandırması

\begin{tabular}{|c|c|c|c|c|c|c|}
\hline \multirow{2}{*}{ Çeşitler } & \multicolumn{5}{|c|}{ Uygulama } & \multirow[b]{2}{*}{ Ort. } \\
\hline & 0 & Zn1 & $\mathrm{Zn} 2$ & Zn3 & Zn4 & \\
\hline Efe & $5.886 \mathrm{~d}-\mathrm{g}$ & 5.883 e-h & $6.033 \mathrm{bc}$ & $5.86 \mathrm{ghl}$ & 5.97 cde & $5.92 \mathrm{BC}$ \\
\hline Hamzadere & $5.973 \mathrm{~cd}$ & $6.07 \mathrm{~b}$ & $6.030 \mathrm{bc}$ & $6.19 \mathrm{a}$ & $6.00 \mathrm{bc}$ & $6.05 \mathrm{~A}$ \\
\hline Osmancık- 97 & $5.88 \mathrm{fgh}$ & $5.95 \mathrm{c}-\mathrm{f}$ & $5.976 \mathrm{c}$ & $5.98 \mathrm{bc}$ & $6.00 \mathrm{bc}$ & $5.95 \mathrm{~B}$ \\
\hline Pașalı & $5.79 \mathrm{hl}$ & $5.98 \mathrm{bc}$ & $6.033 \mathrm{bc}$ & $5.77_{1}$ & $6.00 \mathrm{bc}$ & $5.91 \mathrm{C}$ \\
\hline Ort. & $5.88 \mathrm{C}$ & $5.97 \mathrm{~B}$ & $6.01 \mathrm{~A}$ & $5.95 \mathrm{~B}$ & $5.99 \mathrm{AB}$ & \\
\hline
\end{tabular}

LSD çeşit $=0.039$, LSD uyg. $=0.044$, LSD çeşit $\mathrm{x}$ uyg. int. $=0.088$

\section{Pirinç tane genişliği}

Denemede kullanılan çeltik çeşitleri ve çinko uygulamalarının pirinç tane genişliğine etkisine ilişkin ortalama değerler Çizelge 3'de verilmiştir.
Çizelge 3.'ün incelenmesinden anlaşılacağı üzere çeşit, çinko uygulaması ve çeşit x çinko uygulama interaksiyonu' nun pirinç tane genişliği üzerine etkisi istatistiksel olarak önemli görülmüştür.

Çizelge 3. Çinko uygulamasının çeltik çeşitleri pirinç tane genişliği (mm) üzerine etkileri ve gruplandırması

\begin{tabular}{|c|c|c|c|c|c|c|}
\hline \multirow{2}{*}{ Çeşitler } & \multicolumn{5}{|c|}{ Uygulama } & \multirow[b]{2}{*}{ Ort. } \\
\hline & 0 & Zn1 & $\mathrm{Zn} 2$ & Zn3 & Zn4 & \\
\hline Efe & $2.59 \mathrm{~d}-\mathrm{g}$ & $2.53 \mathrm{gh}$ & $2.61 \mathrm{c}-\mathrm{f}$ & $2.62 \mathrm{c}-\mathrm{f}$ & $2.66 \mathrm{abc}$ & $2.60 \mathrm{~B}$ \\
\hline Hamzadere & $2.56 \mathrm{fg}$ & $2.67 \mathrm{abc}$ & $2.56 \mathrm{fg}$ & $2.72 \mathrm{a}$ & $2.70 \mathrm{ab}$ & $2.64 \mathrm{~A}$ \\
\hline Osmancık- 97 & $2.48 \mathrm{hl}$ & $2.58 \mathrm{efg}$ & $2.66 \mathrm{a}-\mathrm{d}$ & $2.65 \mathrm{~b}-\mathrm{e}$ & $2.67 \mathrm{abc}$ & $2.61 \mathrm{~B}$ \\
\hline Paşalı & $2.57 \mathrm{fg}$ & $2.55 \mathrm{fg}$ & $2.55 \mathrm{fg}$ & $2.53 \mathrm{gh}$ & 2.441 & $2.53 \mathrm{C}$ \\
\hline Ort. & $2.55 \mathrm{C}$ & $2.58 \mathrm{~B}$ & $2.59 \mathrm{AB}$ & $2.63 \mathrm{~A}$ & $2.62 \mathrm{AB}$ & \\
\hline
\end{tabular}

LSD çeşit $=0.032$, LSD uyg. $=0.036$, LSD çeşit $\mathrm{x}$ uyg. int. $=0.073$

Çinko uygulamalarının pirinç tane genişliğine de etkisi çeşitlere göre değişiklik göstermiştir. Çinko x uygulama interaksiyonu incelendiğinde en kısa pirinç tane genişliği $2.44 \mathrm{~mm}$ ile Paşalı çeşidinin Zn4 uygulamasından, en uzun pirinç tane genişliği ise $2.72 \mathrm{~mm}$ ile Hamzadere çeşidinin Zn3 uygulamasında elde edilmiştir. Paşalı çeşidinde çinko dozu arttıkça pirinç tane genişliğinde azalma görülürken Osmancık-97 çeşidinde Zn3 uygulamasına kadar artış görülmüş ve doz artışı ile küçülme oluşmuştur. Diğer çeşitlerde ise doz artışına göre farklılık görülmüştür (Çizelge 3).

Diğer çalışmalarda elde edilen sonuçlarda ise Can (2011), yapmış olduğu çalışma sonucunda ortalama pirinç tane genişliğini $2.98 \mathrm{~mm}$ bulurken, Toksal (1991), çalışmasında ortalama pirinç tane enini 2.50 mm olarak bulmuştur. Maqsood ve ark. (2013), çeltik tane genişliğini ortalama $1.6 \mathrm{~mm}$ bulurken,
Zeng ve ark. (2001), çalışma sonucunda çeltik tane genişliğinde 2.4-4.9 $\mathrm{mm}$ arasında değerler elde etmiştir.

Bulgularımız bazı araştırıcıların sonuçları ile benzerlik gösterirken bazı araştırıcıların sonuçları ile farklılıklar gösterdiği görülmektedir. $\mathrm{Bu}$ farklılıkların denemelerdeki uygulama farklılıklarından kaynaklandığı sanılmaktadır.

\section{Kırıksız randıman}

Denemede kullanılan çeltik çeşitleri ve çinko uygulamalarının kılçıksız randıman değerlerine etkisine ilişkin ortalama değerler Çizelge 4'de verilmiştir.

Çizelge 4'ün incelenmesinden anlaşılacağı üzere çeşit, çinko uygulaması ve çeşit $\mathrm{x}$ çinko uygulama interaksiyonunun kılçıksız randıman değerleri üzerine etkisi istatistiksel olarak önemli olmamıştır.

Çizelge 4. Çinko uygulamasının çeltik çeşitlerinde kırıksız pirinç randımanı (\%) üzerine etkileri ve gruplandirması

\begin{tabular}{|c|c|c|c|c|c|c|}
\hline \multirow{2}{*}{ Çeşitler } & \multicolumn{5}{|c|}{ Uygulama } & \multirow[b]{2}{*}{ Ort. } \\
\hline & 0 & Zn1 & $\mathrm{Zn} 2$ & Zn3 & Zn4 & \\
\hline Efe & 54.50 & 58.06 & 58.43 & 58.93 & 57.96 & 57.58 \\
\hline Hamzadere & 55.00 & 54.20 & 55.50 & 57.00 & 58.23 & 55.98 \\
\hline Osmancık- 97 & 53.23 & 59.40 & 55.86 & 60.81 & 55.73 & 57.01 \\
\hline Pașalı & 54.53 & 57.80 & 55.86 & 51.20 & 54.40 & 54.76 \\
\hline Ort. & 54.31 & 57.36 & 56.41 & 56.98 & 56.58 & \\
\hline
\end{tabular}


Çizelge 4'te görüldüğü gibi, elde edilen sonuçlar istatistik olarak önemli bulunmamış olsa da çalışma sonucu ile kırıksız pirinç randımanı \% 51.20-60.81 arasında değişim göstermiştir.

Konuyla ilgili yapılan çalışmalarda, Beşer ve Gençtan (1996), kırıksız pirinç randımanını \% 59.8-67.5 arasında bulurken, Kahraman (2012), kırıksız pirinç randımanını \% 57.9-66.2 arasında, Çalışmada bulmuş olduğumuz sonuçlar ile Beşer ve Gençtan (1996), ve Kahraman (2013),'ün bulmuş oldukları değerler arasında olup sonuçlar benzerlik göstermiştir.

\section{Protein oranı}

Denemede kullanılan çeltik çeşitleri ve çinko uygulamalarının protein oranına etkisine ilişkin ortalama değerler Çizelge 5'de verilmiştir.

Çizelge 5'in incelenmesinden anlaşılacağı üzere çeşit, çinko uygulaması ve çeşit $x$ çinko uygulama interaksiyonunun protein oranına etkisi istatistiksel olarak önemli görülmüştür.

Çizelge 5. Çinko uygulamasının çeltik çeşitlerinde protein oranı (\%) üzerine etkileri ve gruplandırması

\begin{tabular}{|c|c|c|c|c|c|c|}
\hline \multirow{2}{*}{ Çeşitler } & \multicolumn{5}{|c|}{ Uygulama } & \multirow[b]{2}{*}{ Ort. } \\
\hline & 0 & Zn1 & $\mathrm{Zn} 2$ & Zn3 & $\mathrm{Zn} 4$ & \\
\hline Efe & $10.36 \mathrm{~d}-\mathrm{g}$ & $10.24 \mathrm{efg}$ & $11.77 \mathrm{~b}$ & $13.14 \mathrm{a}$ & $10.67 \mathrm{de}$ & $11.23 \mathrm{~A}$ \\
\hline Hamzadere & $10.24 \mathrm{efg}$ & $10.49 \mathrm{def}$ & $10.57 \mathrm{de}$ & $10.50 \mathrm{def}$ & $10.22 \mathrm{efg}$ & $10.40 \mathrm{~B}$ \\
\hline Osmancık- 97 & $10.89 \mathrm{~d}$ & $9.72 \mathrm{~g}$ & $8.74 \mathrm{~h}$ & $10.92 \mathrm{~cd}$ & $8.43 \mathrm{~h}$ & $9.74 \mathrm{C}$ \\
\hline Pașalı & $11.93 \mathrm{~b}$ & $11.54 \mathrm{bc}$ & $13.09 \mathrm{a}$ & $9.86 \mathrm{fg}$ & $10.47 \mathrm{def}$ & $11.37 \mathrm{~A}$ \\
\hline Ort. & $10.85 \mathrm{~A}$ & $10.49 \mathrm{~B}$ & $11.04 \mathrm{~A}$ & $11.10 \mathrm{~A}$ & $9.94 \mathrm{C}$ & \\
\hline
\end{tabular}

LSD çeşit $=0.286$, LSD uyg. $=0.320$, LSD çeşit $x$ uyg. int. $=0.64$

Çinko uygulamalarının protein oranına etkisi çeşitlere göre değişiklik göstermiştir. Çeşit x çinko uygulama interaksiyonu incelendiğinde en düşük protein oranı (\% 8.43) Osmancık-97 çeşidinin Zn4 uygulamasindan elde edilirken, en fazla protein oranı ise Paşalı çeşidinin Zn2 uygulamasında (\% 13.09) belirlenmiştir. Genel olarak değerlendirildiğinde çeşitlerde Zn2 ve Zn3 uygulamalarına kadar protein oranlarında artış olmuş ve ve daha sonra belirli düzeyde bir azalmanın olduğu görülmüştür. (Çizelge 5).

Panda ve Sahu (1999), çalışmasında çinko uygulamalarının protein oranını artırdığını ve çinko dozunun daha fazla artması ile protein oranın azaldığını belirtmiştir. Toksal (1991), ham protein oranını \% 6.93-8.97 arasında değer bulurken, Donduran (2014), protein oranlarını \% 5.64-8.86, Ahmad ve ark. (2013), protein oranını \% 6.19-6.30, Hakoomat ve ark (2014), ise protein oranını \% 9.6810.31 arasında bulmuştur. Bulgularımızın belirtilen çalışmalarla benzerlik gösterdiği görülmektedir.

\section{Sonuç ve Öneriler}

Bazı çeltik (Oryza sativa L.) çeşitlerinde çinko uygulamasının bazı kalite özellikleri üzerine etkilerinin belirlenmesi amaciyla yapılan bu araştırma sonucunda, çinko uygulamalarının denemede kullanılan çeltik çeşitleri üzerine bin tane ağırlığı, pirinç tane uzunluğu, pirinç tane genişliği ve protein oranı bakımından etkisinin istatistiksel olarak önemli olduğu, fakat kırıksız pirinç randımanı bakımından ise etkisinin önemsiz olduğu görülmüştür.

Bin tane ağırlığı 35.92-41.40 g arasında değișim göstermiş ve en düşük bin tane ağırlığı Osmancık 97 çeşidinde Zn1 uygulamasından, en yüksek ise hamzadere çeşidinde Zn2 uygulamasından elde edilmiştir.

Pirinç tane uzunlukları 5.77-6.19 mm arasında değişim göstermiştir. En kısa pirinç tane uzunluğu Paşalı çeşidinde Zn3 uygulamasından, en uzun pirinç tane uzunluğu ise Hamzadere çeşidinde yine Zn3 uygulamasından elde edilmiştir.

Pirinç tane genişlikleri ise 2.44-2.92 mm arasında değişmiş ve en küçük pirinç tane genişliği Paşalı çeşidinde Zn4 çinko uygulamasından, en büyük pirinç tane genişliği ise Hamzadere çeşidinde Zn3 çinko uygulamasından elde edilmiştir.

Çinko uygulamalarının çeltik çeşitlerinde Kırık randımanı üzerine etkisi önemsiz çıkmasına rağmen, kırık randımanı \% 51.20-60.81 arasında değişmiştir.

Protein oranları ise \% 8.43-13.14 arasında varyasyon göstermiş ve en düşük protein oranı Osmancık 97 çeşidinde Zn4 çinko uygulamasında, en düşük protein oranı ise Efe çeşidinde Zn3 uygulamasından elde edilmiştir.

Gübre uygulamasının çeltik bitkisinde kalite üzerine direk olarak etkisi olduğunu ve iyi bir kalite düzeyine ulaşmak için toprak tahlili sonuçları ile oluşturulacak gübreleme programına göre gübreleme işleminin yapılması gerekmektedir. 
Çeltikte çinkolu gübre uygulamasının bitkinin kalite özelliklerine etkisini görme bakımından büyük önem arz etmektedir. Konuyla ilgili daha net sonuçlar alabilmek için uzun süreli tarla ve sera denemelerinin yapılması yararlı olacaktır.

\section{Kaynaklar}

Abid, M., Ahmad, N., Jahangir, M., Ahmad, I,. 2002. Effect of zinc, iron and manganes on growth and yield of rice (Oryza sativa L.). Pak J Agri. 101. 39 (3). Multan. Pakistan.

Ahmad, A., Afzal, M., Ahmad, A.U.H., Tahir, M., 2013.Effect of foliar application of silicon on yield and quality of rice (Oryza Sativa L.).Cercetari Agronomice in Moldova. 3 (155):21-28.

Arcasoy, A. 1997. İnsan sağlığında çinkonun önemi. I. Ulusal Çinko Kongresi, 12-16 Mayıs 1997, Eskişehir.

Beşer, N., Gençtan, T., 1996. Dört sulama yönteminin çeltikte bazı kalite özellikleri ve verime etkisi. Trakya Tarımsal Araştırma Enstitüsü.

Can, V., 2011. Çeltik yetiştiriciliğinde bazı organik materyallerin kullanımı. Yüksek Lisans Tezi, Çanakkale Onsekiz Mart Üniversitesi, Fen Bilimleri Enstitüsü, Tarla Bitkileri Anabilim Dalı, Çanakkale.

Donduran, D.Ö., 2014. Ülkemizde işlenen bazı çeltik çeşitlerinin kalite ve biyoaktif özelliklerinin incelenmesi. Yüksek Lisans Tezi, Çanakkale On Sekiz Mart Üniversitesi, Fen Bilimleri Enstitüsü, Gıda mühendisliği Anabilim Dalı, Çanakkale.

Dok, M., M. Şahin, C. Özcan, İ. Sezer, A. Horuz ve M.A. Özyazıcı, 2013.“Farklı Çeltik Çeșitlerinin Çinko Etkinliklerinin Belirlenmesi”, Türkiye 10. Tarla Bitkileri Kongresi, 10-13 Eylül, Konya, Bildiriler Kitabı, S: 138-147.

Hakoomat, A., Hasnain, Z., Sahanzad, A.N., Sarwar, N., Qureshi M.K., Khaliq, S., Qayyum, M.F., 2014. Nitrogen and zinc interaction improves yield and quality of submerged basmati rice (Oryza sativa L.). Natulae botanicae horti agrobotanici cluj-napoca. 42 (2):372-379.

Kahraman, Ş., 2012. Diyarbakır yöresinde çeltik yetiştiriciliğinde organik tarım olanaklarının araștırılması. Yüksek Lisans Tezi, Dicle Üniversitesi, Fen Bilimleri Enstitüsü, Tarla Bitkileri Anabilim Dalı, Diyarbakır.
Maqsood, M., Shehzad, M.A., Ali, S.N.A, Iqbal, M., 2013. Rice cultures and nitrogen rate effects on yield and quality of rice (Oryza sativa L.) Turkish Journal of Agriculture and Forestry 37: 665-673.

Özcan, H., 2004. Çinko uygulamasının bazı çeltik çeşitlerinde verim ile tanede çinko, fosfor ve fitin asidi konsantrasyonuna etkisi. Doktora Tezi, Ankara Üniversitesi, Fen Bilimleri Enstitüsü, Toprak Anabilim Dalı, Ankara.

Panda, R., Sahu, S.K. 1999. Effects of zinc on the biochemi production parameters of the rice plant (Oryza sativa L.). Cytobiows, 98: 388, 105-112.

Sezer, İ., Köycü, C., 1999. Kızılırmak vadisinde yetiștirilebilecek çeltik çeșit ve hatlarının belirlenmesi üzerine bir araştırma. Türkiye 3. Tarla Bitkileri Kongresi, 15-18 Kasım 1999, Adana.

Sezer, İ. ve Z. Mut, 2004."Samsun İlinde Çeltik Tarımının Durumu ve Üretimi Artırmak İçin Öneriler", Gazi Osman Paşa Üniversitesi, Ziraat Fakültesi Dergisi, Cilt:21 (1) S:57-66.

Sezer, İ., Z. Mut ve F. Öner, 2007. “Çeltikte (Oryza sativa L.) Kırıklı Randımana Etkili Faktörler”, Türkiye VII. Tarla Bitkileri Kongresi, 25-27 Haziran, Erzurum, Bildiriler Kitabı, S:226-230 .

Sezer, İ., H. Akay, F. Öner ve M. Şahin, 2012. “Çeltik Üretim Sistemleri”, Türk Bilimsel Derlemeler Dergisi, Cilt:5 (2) S: 6-11.

Sezer İ., Akay H., Şişman A., Şenocak.H.S. 2015. Çeltikte Kalite Kavramı ve Kaliteyi Etkileyen Faktörlerin irdelenmesi 11. Tarla Bitkileri Kongresi 7-10 Eylül 2015 Çanakkale. 305-308.

Sürek, H., 2005. Çeltik ürün raporu. Trakya Tarımsal Araștırma Enstitüsü. Edirne.

Toksal, A., 1991. Çarşamba ovasında bazı çeltik ( Oryza sativa $\mathrm{L}$ ). çeşitlerinin verim, verim öğeleri ve tane kalitesi üzerine bir araştırma. Yüksek Lisans Tezi, Ondokuz Mayıs Üniversitesi, Fen Bilimleri Enstitüsü, Samsun.

Ünan, R., 2011. Çeltikte (Oryza sativa L.) Trinexapac-Ethyl dozları ve ekim sıklığının yatma ile bazı agronomik ve kalite özelliklerine etkisi. Yüksek Lisans Tezi, Ondokuz Mayıs Üniversitesi, Fen Bilimleri Enstitüsü, Tarla Bitkileri Anabilim Dalı. Samsun.

Zeng, Y., Li, Z., Yang, Z., Wang, X., Shen, S., Zhang, H., 2001. Ecological and genetic diversity of rice germplas in Yunnan. Issue No.125. China.Pp 24-28. 